\title{
BEST PRACTICES NILAI-NILAI KARAKTER MULTIKULTURAL DI PONDOK PESANTREN NGALAH, PASURUAN
}

\author{
Achmad Yusuf \\ Universitas Yudharta Pasuruan, East Java, Indonesia \\ achys@@yudharta.ac.id
}

\begin{abstract}
This research aims to uncover and describe the best practices of the multicultural character value of Pondok Pesantren Ngalab Pasuruan. The approach used is qualitative-naturalistic, with Case study type (case study). Data consists of primary and skunder data. The informant is determined through purposive sampling technique. Snowball sampling. Data collected 1) in-depth interviews, 2) participant observations and 3) documentation studies. Analysis of data using descriptive technique of interactive model L) data reduction, 2) data presentation and 3) withdrawal conclusion/verification. The results of this study concluded that Best practices the value of multicultural characters in Pesantren Ngalah, Pasuruan is: (1) The value of religious characters, (2) The value of the buman character is a core value that grows other values include; (a) The character of caring and the students' familiosity; (b) The value of the Brotherhood character, (c) the character of affection, (d) egalitarian/ the line of doctrine; (3) inclusive-pluralist characters; The value of an inclusive-pluralist character (open accepts differences). (4) Character value tolerance (TASAMUH); Tolerance value of students, including; (a) Tolerance in interfaith Association, (b) to say greetings to Non Muslims, (c) Non Muslims enter the mosque. (5) Luwas and Luwes (moderate) character values; (6) Democratic character value, and (7) nationalist character value.

Keywords: $\mid$ Best Practices, Multicultural V alues,
\end{abstract}

\section{PENDAHULUAN}

Maraknya aksi radikalisme dan terorisme atas nama Islam di dunia maupun Indonesia sedikit banyak telah menempatkan umat Islam sebagai pihak yang dipersalahkan. Ajaran jihad dalam Islam seringkali dijadikan sebagai sumber utama terjadinya kekerasan atas nama agama yang diasosiasikan bersumber dari Pesantren. Pesantren dituduh telah mendidik para santrinya untuk melakukan aksi radikal. Selain itu, Pesantren juga seringkali diasosiasikan sebagai 'markas atas sentral pemahaman Islam yang sangat fundamental' yang kemudian menjadi akar bagi gerakan radikal mengatasnamakan Islam. Hal ini didasarkan pada fakta bahwa semua pelaku teror bom tersebut adalah orang-orang pesantren. Trio bersaudara-Mukhlas, Amrozi, dan Ali Imron—adalah keluarga Pesantren al-Islam Lamongan Jawa Timur, di samping itu juga termasuk alumni Pesantren al-Mukmin Ngruki Solo. Hal ini berdampak pada relasi kemanusiaan dalam menjalin kerukunan antar umat beragama. Disisi lain, umat Islam memiliki sekat dan jarak dalam berinteraksi, bergaul dan bertemu dengan nonmuslim. Hal ini sebagai salah satu pemicu adanya konflik keagamaan yang menyebabkan radikalisme agama.

Namun bertolak belakang dengan fenomena di Pesantren Ngalah Pasuruan, Berdasarkan studi pendahuluan bahwa Pesantren Ngalah seringmelibatkan santri bersama non muslim di pesantren Ngalah melalui live in meliputi: (1) live in 100 pendeta tahun 2010 selama 3 hari tinggal di Pesantren hidup bersama santri kegiatan ini sebagai tindak lanjut forum komunikasi antar umat beragama, (2) Live in pendeta perwakilan yang berasal dari berbagai negara, mulai dari Filiphina, Srilanka, Papua, Jerman dan Indonesia (Medan, Nias) tahun 2011, (3) live in pendeta perwakilan dari Jerman Indonesia tahun 2015. (8) live in 
"Studi antar umat beragama oleh Institut Pendidikan Theologia Bale Wiyata Gereja Kristen Jawi Wetan pada tanggal 10-16 Oktober 2016, (9) Live in Biarawati "kursus Kursus pembekalan Misionaris terdiri dari 14 orang, 11 Biarawati, 1 Romo dan 2 Frater 2017, (10) Live In Mahasiswa GMKI Kegiatan parade Kebangsaan yang dilakukan pada tanggal 2-6 Oktober 2017. (11) Live In remaja non muslim selama 3 hari "Camp Remaja Lintas Iman” pada tanggal 21 hingga 23 Juni 2019. Kegiatan yang bertajuk “Amazing Youth" tersebut diadakan sebagai sarana belajar hidup bersama dengan saling menghargai berbagai perbedaan.

Hal ini berdasarkan pada karakteristik Islam yang ditampilkan oleh para ulama pesantren sebagaimana Nabi SAW mengajarkannya adalah penanaman dan pengembangan nilai-nilai infitab (inklusif), tawassut (moderat), musawah (persamaan), dan tawazun (seimbang). Karena itu maka pesantren tampil pula sebagai agen pembudayaan nilai, norma, sekaligus pesan-pesan keagamaan yang memiliki nilai harmoni, kerukunan, persatuan, dan kedamaian bahkan para ahli menilai pesantren mempunyai peran yang cukup signifikan dalam melestarikan budaya lokal, termasuk memelihara nilai-nilai dan tatanan sosial yang harmonis di sekelilingnya ${ }^{2}$. Berdasarkan fenomena-fenomena yang diuraikan dalam konteks tersebut, penelitian ini akan mengkaji mengungkap tentang Best Practices Nilai Karakter Multikultural di Pesantren Ngalah Pasuruan.

\section{METODE}

Pendekatan yang digunakan dalam penelitian ini kualitatif-naturalistik, dengan jenis studi kasus (case study) karena lebih menekankan pada proses-proses aktivitas social alamiah mencakup aktivitas tentang (1) Best Practices Nilai-nilai karakter Multikultural di Pesantren Ngalah Pasuruan. Data terdiri dari data primer dan skunder. Informan ditentukan melalui Pertama, teknik purposive sampling. Kedua, snowball sampling. Data dikumpulkan dengan tiga teknik, yaitu: 1) wawancara mendalam (indepth interview); 2) observasi partisipan (partisipant observation); dan 3) studi dokumentasi (study document) ${ }^{3}$. Prosedur analisis data menggunakan teknik deskriptif model interaktif yaitu: l) reduksi data, 2) penyajian data dan 3) penarikan kesimpulan/verifikasi. Uji keabsahan menggunakan triangulasi. Terdapat tiga macam trianggulasi yang dipergunakan untuk mendukung dan memperoleh keabsahan data, yaitu trianggulasi sumber, teknik, dan waktu. ${ }^{4}$

\section{HASIL DAN PEMBAHASAN}

\section{Nilai-nilai Karakter Multikultural Santri Pesantren Ngalah Sengonagung Purwosari Pasuruan}

Islam dalam historisnya, Rasulullah SAW menegaskan misi utama pendidikan Islam adalah dalam mendidik manusia adalah mengupayakan pembentukan akhlak yang baik (good character). ${ }^{5}$ Pendidikan karakter memiliki peran yang sangat penting dalam membangun kehidupan manusia yang pada pada hakikatnya manusia mempunyai kedudukan sebagai makhluk individu dan juga makhluk sosial, serta sebagai makhluk yang tidak terlepas dari lingkungannya. Adapun tujuan Pendidikan Islam adalah mengembangkan potensi yang dimiliki peserta didik agar menjadi manusia yang beriman dan bertaqwa kepada Tuhan Yang Maha Esa, berakhlak mulia, sehat, berilmu, cakap, kreatif, mandiri, dan menjadi

\footnotetext{
${ }^{1}$ Lihat juga https://www.suarakristen.com/2017/10/03/eratkan-kebersamaan-pengurus-pusat-gmki-kunjungipesantren-ngalah-pasuruan-jawa-timur/

2 an-Nahidil, Nunu Ahmad. 2016 "Pesantren dan Dinamika Pesan Damai” dalam Edukasi, Jurnal Penelitian Agama dan Keagamaan, Vol.4 No.3 (Jakarta: Puslitbang Pendidikan Agama dan Keagamaan, Badan Litbang dan Diklat Departemen Agama RI, 2016), hlm. 18

${ }^{3}$ Bogdan dan Biklen, Qualitative Research..., h. 119-143

${ }^{4}$ Sugiyono, Metode Penelitian Kuantitatif, Kualitatif dan R \& D, (Bandung: Alfabeta, 2010), hlm. 273

${ }^{5}$ Abdul Majid dan Dian Andayani, Pedidikan Karakter dalam Perspektif Islam, hlm. 29
} 
warga negara yang demokratis serta bertanggungjawab. ${ }^{6}$ Adapun best practises karakter Multikultural di Pondok Pesantren Ngalah, sebagai berikut;

\section{Nilai Karakter Religius}

Religius adalah sikap dan prilaku yang patuh dalam melaksanakan ajaran agama yang dianutnya, toleran terhadap pelaksanaan agama lain, dan hidup rukun dengan pemeluk agama lain. Berdasarkan hasil analisis peneliti pada lokasi penelitian, pengembangan karakter religius santri tercermin pada sikap santri dalam melaksanakan rutinitas sholat berjamaah di masjid Darut Taqwa Pesantren Ngalah dengan penuh antusias, tertib dan disiplin. Dalam konteks ini nilai religius di pesantren ditemukan pada saat santri mengikuti aktivitas harian, mingguan, bulanan santri pesantren melalui kelas, kamar asrama dan budaya Pesantren Ngalah. Hal ini di perkuat dengan hasil dokumentasi tentang peraturan pesantren salah satunya adalah berjamaah sholat Fardhu diwajibkan bagi semua santri, kecuali Sholat Dhuhur. Adanya peraturan berjamaah ini bertujuan untuk membiasakan santri agar menjadi santri yang disiplin.

Temuan karakter religious di atas senada dengan apa digagas dan dikembangkan oleh Kemendiknas bahwa nilai karakter yaitu "Sikap dan perilaku yang patuh dalam melaksanakan ajaran agama yang dianutnya, toleran terhadap pelaksanaan ibadah agama lain, dan hidup rukun dengan pemeluk agama lain." Lebih lanjut Mustari menyatakan bahwa "Religius adalah nilai karakter dalam hubungannya dengan Tuhan. Ia menunjukkan bahwa pikiran, perkataan, dan tindakan seseorang yang diupayakan berdasarkan pada nilai-nilai ketuhanan/atau ajaran agamanya. ${ }^{7}$ Lebih lanjut menurut Asmani yaitu Religius adalah pendidikan yang menekankan nilai-nilai religius, seperti nilai ibadah, nilai jihad, nilai amanah, nilai ikhlas, akhlak dan kedisiplinan serta keteladanan. Pendidikan karakter religius umumnya mencangkup pikiran, perkataan, dan tindakan seseorang diupayakan selalu berdasarkan pada nilai-nilai ketuhanan atau ajaran agama. ${ }^{8}$

Selain pada rutinitas di atas, karakter religius santri tercermin pada waktu mengikuti tawajuhan yang dilaksanakan setiap selesai Sholat Isya yang di pimpin langsung oleh Kiai H. M. Sholeh Bahruddin. Di dalam mengikuti tawajuhan ini sikap santri dengan penuh kehusyuan membaca drikir atau bacaanbacaan pada saat tawajuh agar selalu dekat dengan sang pencipta. Tawajuhan ini dilaksanakan secara rutin oleh santri yang dipimpin oleh Kiai M. Sholeh setiap selesai sholat Isya, dan dilanjutkan oleh masingmasing santri secara individu di kamar atau di masjid untuk berdzikir kepada Allah SWT.

\section{Nilai Karakter Kemanusiaan}

Menurut Majid dalam ajaran Islam dikelompokkan menjadi dua yaitu nilai rabbaniyah dan nilai insaniyah. Nilai rabbaniyah meliputi: Iman, Islam, Ibsan, taqwa, ikhlas, tawakkal, syukur, dan sabar. Sedangkan nilai insaniyah meliputi: silaturrahmi, persaudaraan, (ukhuwwah), persamaan, (musawat), adil ('adl) baik sangka, (busn ad-dzan), rendah hati (tawadlu), menepati janji, (wafa') lapang dada (insyirah), perwira (iffah, taafut) hemat, (qawamiyah) dan dermawan (munfiqun). ${ }^{9}$ Dalam konteks pengembangan nilai kemanusiaan di atas, telah tergambar pada sikap-sikap santri Pesantren Ngalah.

Kaitannya dengan nilai karakter multicultural, nilai kemanusiaan ini secara inheren termasuk di dalam nilai-nilai multicultural. Hal ini sebagaimana menurut Aly ada 3 bahwa nilai inti dalam pendidikan multikultural, yaitu: nilai demokrasi, kesetaraan, dan keadilan; nilai kemanusiaan, kebersamaan, dan

'Undang-Undang Republik Indonesia Nomor 20 Tahun 2003 tentang Sisdiknas \& Peraturan Pemerintah RI Tabun 2013 tentang Standar Nasional Pendidikan serta Wajib Belajar (Bandung: Citra Umbara, 2014), hlm. 6.

${ }^{7}$ Muhamad Mustari. Nilai Karakter Refkleksi untuk. Pendidikan karakter. (Yogyakarta: LaksBank PRESSindo, 2011) hlm. 1

8 Jamal Ma'mur Asmani, Buku Panduan Internalisasi Pendidikan Karakter di Sekolah, (Yogjakarta: Diva Press,2012), h. 37 ${ }_{9}^{9}$ Nurcholis Majid dalam Ridwan, Pengembangan Nilai-Nilai Islami dalam Pembelajaran PAI di SMA (El Hikam Press, 2003$)$ hlm. 23 
kedamaian; serta sikap sosial, yaitu: pengakuan, penerimaan, dan penghargaan kepada orang lain. ${ }^{10}$ Sementara Faridah Hanun dengan istilah berbeda membagi nilai multikultural menjadi 3 nilai inti dari pendidikan multikultural berupa demokratis, humanisme, pluralism. ${ }^{11}$ nilai kemanusiaan di Pesantren Ngalah merupakan nilai yang di jungjung tinggi di Pesantren Ngalah, hal ini dibuktikan pernyataan Kiai tentang asas dan tujuan pesantren Ngalah sebagai berikut;

"Darut Taqwa berwawasan Rahmatan Lil 'Alamin dan berasaskan Pancasila selama-lamanya. (KH. Bahruddin, 1977)

Dengan tujuan;

1. Agar tidak lupa dengan rumah sendiri

2. Agar tidak berjalan di tempat

3. Agar mempunyai wawasan yang luas dan luwes

Pondok Pesantren Ngalah berbeda dengan yang lain. Karena di dalamnya ada bimbingan Thariqah, diantara kewajibannya adalah; mbagusi kabeh konco yang menjunjung tinggi nilai-nilai perikemanusiaan dan berwawasan kebangsaan."12

Pernyataan di atas menyatakan bahwa pesantren Ngalah memiliki orientasi yang mangacu pada nilai kemanusiaan sebagai bentuk perwujudan dari visi, misi, dan tujuan adanya Pesantren Ngalah Pasuruan. Pernyataan ini juga senada dengan pendapat Ali, bahwa orientasi kemanusiaan ini relevan dengan konsep pendidikan dalam Islam, yang lazim disebut dengan hablum minan naas. Dalam konsep ini manusia ditempatkan sebagai makhluk terbaik (absani taqwim) di antara makhluk- makhluk Allah di muka bumi ini. Paralel dengan konsep ini, Islam memperkenalkan doktrin tentang pentingnya memelihara kelangsungan hidup manusia. Doktrin ini, menurut Hassan Hanafi sebagaimana yang dikutip oleh Abdullah Aly mencakup 5 (lima) tujuan yang asasi, yaitu: (1) pemeliharan kehidupan manusia sebagai tolok ukur utama, (2) pemeliharaan akal manusia, (3) perjuangan untuk kebenaran pengetahuan, (4) menjunjung tinggi harkat manusia dan kehormatan masyarakat, serta (5) pemeliharaan kesejahteraan individu dan kelompok. Kelima hal di atas merupakan etika universal yang dapat dijadikan dasar untuk membangun hubungan yang baik sesama manusia (hablum minan naas) dalam rangka memelihara kelangsungan hidup manusia di muka bumi ini. ${ }^{13}$

Selain asas dan tujuan didirikannya Pesantren Ngalah di atas, ungkapan yang sering diamanahkan oleh dan sering diulang-ulang ungkapan Kiai adalah santriku kabeh awakmu nak, lek iso gembol uwong tak acungi jempol siji, tapi nek iso nguwongno uwong tak acungi jempol loro" ${ }^{14}$ di lain kesempatan pada saat wisuda Kiai selalu menekankan pada nilai-nilai manusiawi serta menjunjung tinggi nilai-nilai kemanusiaan. Hal ini juga di pertegas dengan dawuhnya "uwong kudu iso gembol uwong, lek gak iso gembol uwang berarti g iso nguwongno uwong, lek gak iso nguwongno uwong berarti duduk uwong",15

Dari beberapa ungkapan di atas, mengindikasikan bahwa karakter manusiawi ditanamkan kepada santri agar karakter-karakter yang dimiliki santri bermuatan pada nilai-nilai manusiawi serta dapat menghormati dan menjunjung tinggi nilai-nilai kemanusiaan yang berorientasi pada kedamaiaan serta dapat yaitu memposisikan manusia yang lain sebagaimana layaknya kedudukan manusia itu sesuai dengan harkat dan martabatnya, karena manusia itu makhluk yang paling sempurna di banding dengan makhluk

10 Abdullah Aly, Pendidikan Islam Multikultural di Pondok Pesantren, Telaah terhadap Kurikulum Pondok Pesantren Modern Islam Assalam Surakart, Yogyakarta: Pustaka Pelajar, 2011, hlm. 109

${ }^{11}$ Farida Hanum dan Setya Raharja..Pengembangan Model Pembelajaran Pendidikan Multikultural Menggunakan Modul Sebagai Suplemen Pelajaran IPS di Sekolah Dasar.Jurnal Penelitian Ilmu Pendidikan, Volume04,tahun 2011 Nomor 2. hlm. 115

${ }^{12}$ Pesantren Ngalah, Dokumentasi,(Pasuruan, 31 Juli 2017)

${ }^{13}$ Abdullah Aly, Op. Cit, hlm. 115

${ }^{14}$ KH. M. Sholeh, Pengasuh Pesantren Ngalah, diambil dari beberapa rekaman pada acara Wisuda Diniyah, dan Pendidikan Formal. 16 Juli 2017.

${ }^{15}$ KH. M. Sholeh, Pengasuh Pesantren Ngalah, diambil dari beberapa rekaman pada acara Wisuda Diniyah, dan Pendidikan Formal. 16 Juli 2017 
yang lain. Lebih lanjut Ali menegaskan bahwa nilai kemanusiaan dalam pendidikan multikultural juga berorietasi kepada kedamaian. Nilai kedamaian, yang merupakan cita-cita semua orang yang hidup di tengah-tengah masyarakat yang heterogen. Kedamaian lazim dipahami sebagai keadaan yang harmonis tanpa adanya permusuhan, konflik, dan kekerasan. Dalam ensiklopedi wikipedia yang dikutip oleh Abdullah Aly disebutkan bahwa kedamaian mempunyai tiga arti, yakni: 1) Peace as an absense of war, 2) peace as a selfness act of love, 3) peace as an absence of violence or of evil, presence of jucstice. Atas dasar ini kedamaian hidup dalam suatu masyarakat dapat diwujudkan dengan cara menghindari terjadinya kekerasan, peperangan, dan tindakan mementingkan diri sendiri. ${ }^{16}$

Nilai karakter kemanusiaan di Pesantren Ngalah merupakan core nilai yang menumbuhkan dan mengembangkan nilai karakter multicultural yang lain meliputi;

(1) karakter kepedulian dan kedermawanan santri; hal ini tercermin pada sikap dan perilaku santri yang suka menolong sesama santri di kamarnya seperti membantu dalam hal materi ketika ada anggota kamarnya belum kiriman, mereka dengan senang hati memberikan pinjaman uang. Selain itu, sikap kepedulian dan kedermawanan santri tercermin pada saat mau membeli makanan atau snack, untuk kebutuhan dirinya, namun tidak lupa juga untuk membelikan teman santri kamarnya sesuai dengan jumlah penghuni kamarnya, sikap peduli terhadap orang lain ini menjadi sebuah kebiasaan di Pesantren. ${ }^{17}$

(2) Nilai karakter persaudaraan; hal ini dibuktikan dengan adanya karakter rasa kasih sayang dan rasa persaudaraan pada masing-masing anggota kamar yang satu dengan yang lain. Hal ini juga tercermin pada santri yang lebih tua secara usia mengasihi santri yang lebih muda, serta santri yang lebih muda menghormati yang santri lebih tua. Bahkan mereka saling menganggap sebagai saudara kakak bagi yang lebih tua, dan adik bagi yang lebih muda. Selain itu, pada saat pengajian tafsir pada saat musim santri baru adanya penganggapan anak terhadap semua santri, keluarga ndalem, menganggap anggota kamar yang lebih tua serta santri yang kecil dianggap adik, dan juga saudara yang lebih tua dianggap kakak. Hal ini sebagaimana hasil dokumentasi catatan pengajian tafsir sebagai berikut;

"semua santri disini anakku kabeh. Aku iki Bapakmu, lan Bunyai iku Ibumu, Disini ada

Gus lan Ning iku cacakmu lan mbakyumu nak, seng nggede di kamar iku anggepen cacakmu, mbakyumu, seng emon iku anggepen adhekmu kabeh. Aku disini nggak seneng tukaran."18

Dokumentasi catatan di atas, mengindikasikan bahwa adanya nilai persaudaraan di pesantren Ngalah ini tidak melihat latar belakang santri, semuanya dianggap saudara tidak ada perbedaan, hal ini sebagaimana hasil wawancara dengan kepala Pesantren Ngalah AG bahwa persaudaraan di Pesantren ini mengacu pada prinsip dasar pesantren Ngalah sebagai berikut berikut;

"Pesantren Ngalah adalah pesantren yang memiliki prinsip sebagaimana prinsipnya NU yaitu Ahlussunnah Wal Jama'ah yang mengimplementasikan tiga solidaritas (ukhuwah) meliputi Pertama: Ukhuwah Islamiyah yaitu berbuat baik kepada sesama muslim, kedua Ukhumwah Wathoniyah, yaitu berbuat baik kepada manusia sesama bangsa dan Negara, dan ketiga Ukhuwah Basyariyah/Insaniyah yaitu berbuat baik kepada sesama manusia dengan tanpa membeda-bedakan latar belakang status social--pejabat, penjahat, korak, qori, pencuri, polisi, pedagang, kiai, pengemis, bahkan WTS - status suku-madura, jawa, Kalimantan, Bali, Sumatra, agamaIslam, Hindhu, Buddha, Kristen Katolik, Protestan, Konghucu—ataupun berbeda pandangan, prinsip. ${ }^{19}$

\footnotetext{
16Ibid, hlm. 117

${ }^{17}$ Pesantren Ngalah, Observasi. (Pasuruan, 19 Oktober 2017)

18 Dokumentasi Catatan Tafsir. Pesantren Ngalah (07 Juli 2017)

19 Abdul Ghofur, Wawancara, (Purwosari, 15 Desember 2016).
} 
Nilai karakter persaudaraan merupakan nilai turunan dari nilai kemanusiaan yang telah dikembangankan di Pesantren Ngalah, hal ini karena Pesantren Ngalah mengacu pada prinsip persaudaraan (ukhuwah) yang ada pada prinsip NU yaitu; ukhuwah islamiyah, ukhuwah wathoniyah, dan ukbuwah Basyariyah. Nilai kakrater ersaudaraan ini tercermin pada sikap santri yang tua mengasihi dan menyayangi yang muda, yang muda menghormati yang lebih tua, lebih lanjut adanya sikap penganggapan anggota kamarnya yang lebih muda dianggap sebagai adiknya, begitu juga yang lebih tua dianggap sebagai suadara tua (kakak) walaupun tidak ada hubungan sanak keluarga. Ukhuwah diartikan lebih luas tidak hanya ada hubungan keluarga, namun lebih dari itu yaitu orang yang segolongan, sepaham, seagama, sederajat. ${ }^{20}$

Persaudaraan (ukbuwah) Menurut Quraish Shihab yang mengacu pada al- Quran, ada 4 bentuk persaudaraan yaitu (1) Ukhuwah Ubudiyah, (2) Ukhuwah Insaniyyah atau (basyariyyah), (3) Ukhuwah Wathaniyah wa an-Nasab, (4) Ukhuwah fi ad-din al-islam (persaudaraan antara sesama muslim). ${ }^{21}$

Pertama, Ukhuwah Ubudiyah ini merupakan persaudaraan sesama makhluk dan sama-sama tunduk kepada Allah. Hal ini berdasarkan pada ayat al-Qur'an Q.S al-An'aam ${ }^{22}: 38$

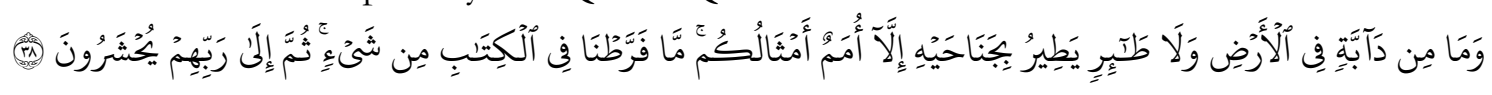

Kedua, Ukhuwah insaniyah atau Ukhuwah basyariyah, yaitu persaudaraan sesama umat manusia tanpa terkecuali. Manusia yang memiliki motivasi dalam menciptakan persaudaraan hakiki yang dikembangkan atas prinsip nilai universal serte menjunjung tinggi nilai-nilai kemanusiaan, karena semua manusia pada hakikatnya sama di hadapan Allah, yang membedakan adalah ketaqwaannya. sebagaimana al-Qur'an Surat al Hujurat ayat 13 sebagai berikut; ${ }^{23}$

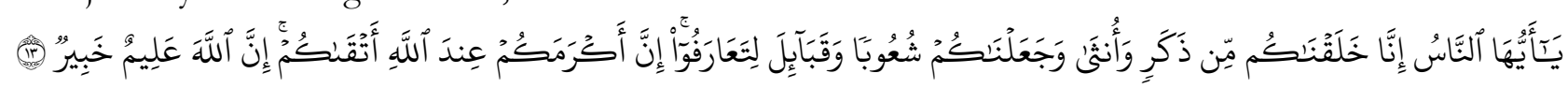

Berdasarkan ayat di atas, bahwa Manusia diciptakan Allah SW'T dengan identitas yang berbedabeda yang terdiri dari laki-laki dan perempuan, bersuku-suku dan berbangsa-bangsa agar mereka saling mengenal dan mempererat tali persaudaraan serta saling memberi manfaat yang satu dengan yang lainnya.

Ayat lain yang menjunjung tinggi nilai dan martabat manusia adalah surat al-Hujuraat ayat $11^{24}$ sebagai berikut;

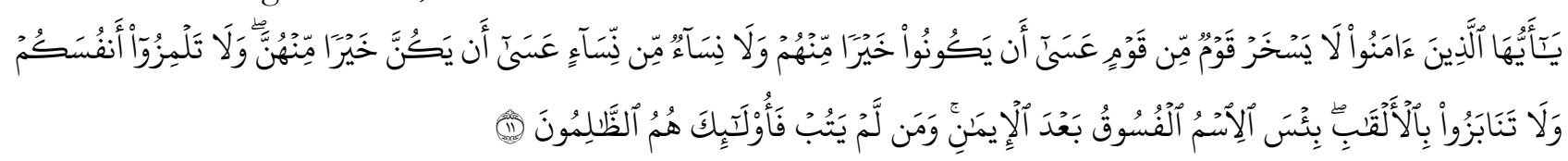

Berdasarkan ayat ini jelaslah bahwa Islam menjunjung tinggi nilai dan martabat kemanusiaan, karena ayat ini mempertegas bahwa orang mukmin dilarang mengejek atau mengolok-olok kaum lain sesama umat manusia, baik laki -laki dan perempuan. Hal ini dapat difahami bahwa jalinan hubungan antara persuadaraan sesame manusia (ukhuwah Insaniyah) menyangkut hal-hal yang berhubungan dengan sikap menjunjung tinggi nilai dan harkat martabat kemanusiaan agar dapat hidup dalam kesejahteraan, berkeadilan, penuh kedamaian serta dapat hidup berdampingan tanpa adanya perbedaan suku, bahasa, agama, bangsa.

${ }^{20}$ Departemen Pendidikan Nasional, Kamus Besar Bahasa Indonesia (Jakarta: Balai Pustaka, 2002), 1003.

${ }^{21}$ M. Quraish Shihab, Membumikan al-Qur" an (Bandung: Mizan, 1998), hal 358

${ }^{23}$ Taufiq Muhammad, Aplikasi MS. Quran In Word Kemenag, Lajnah Pentashih Mushaf al-Quran Kemenag. V.2.2. 2013. QS. al-Hujuraat, (49):13

${ }^{24}$ Taufiq Muhammad, Aplikasi MS. Quran In Word Kemenag, Lajnah Pentashih Mushaf al-Quran Kemenag. V.2.2. 2013 QS. al-Hujuraat, (49):11 
Ketiga, Ukhuwah Wathaniyah wa an-Nasab, persaudaraan dalam jalinan sebangsa dan setanah air walaupun tidak seagama. Konsep ini berdasarkan pada ayat al-Qur'an surat al-A'raf ${ }^{25}$ ayat 65 sebagai berikut;

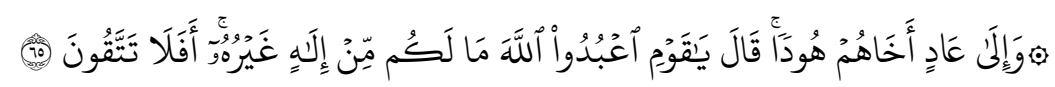

Ayat di atas, menurut Quraish Shihab menjelaskan bahwa guna memantapkan ukhuwah kebangsaan walaupun tidak seagama, pertama kali al-Quran menggarisbawahi bahwa perbedaan merupakan bukum yang berlaku dalam kehidupan ini. Selain perbedaan tersebut merupakan kehendak Allah, juga demi keberlangsungan hidup manusia, sekaligus demi mencapai suatu tujuan kehidupan makhluk di muka bumi ini. ${ }^{26} \mathrm{Hal}$ ini senada sebagaimana menurut Pulungan bahwa cerminan ukhuwah (wathoniyah) kebangsaan ini dapat pula dilihat sebagaimana dalam ketetapan Piagam Madinah yang bertujuan untuk mewujudkan segenap persatuan dan kesatuan sesama warga masyarakat Madinah, yakni persatuan dalam bentuk persaudaraan segenap penduduk Madinah sebagaimana dalam pasal 24 pada piagam tersebut, yakni (orang-orang mukmin dan Yabudi bekerja sama menanggung pembiayaan selama mereka berperang) ${ }^{27}$ ini mengindikasikan bahwa di dalam masyarakat Madinah ada jalinan kerjasama, tolong menolong serta saling menjaga keselamatan dari ancaman luar.

Keempat, Ukhuwah fi ad-din al-islam (persaudaraan antara sesama muslim). Berdasarkan pada alQur'an surat al-Hujuraat ayat 10 sebagai berikut;

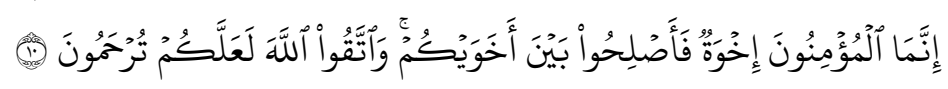

Berdasarkan pada ayat di atas, bahwa setiap mukmin adalah saudara. Sebagaimana Shihab menyatakan bahwa kata innama biasanya digunakan untuk menggambarkan sesuatu yang telah diterima sebagai suatu hal yang telah diketahui oleh semua pihak secara baik. Dengan demikian, penggunaan kata innama dalam konteks penjelasan tentang "persaudaraan antara sesama mukmin" ini, mengisyaratkan bahwa sebenarnya semua pihak telah mengetahui secara pasti tentang semua kaum itu beriman serta bersaudara, sehingga semestinya tidak adanya gangguan dalam persaudaraan ini dari pihak manapun. ${ }^{28}$

\section{(3) Karakter Kasih Sayang}

Berdasarkan hasil observasi bahwa nilai kasih sayang (ramah), antiradikalisme dan terorisme. Berdasarkan pada hasil observasi peneliti, bahwa nilai kasih sayang ini tercermin pada karakter santri di dalam bergaul dengan sesama santri pada aktivitas sehari-hari di tingkat kamar, asrama, maupun lintas asrama, santri yang lebih tua mengasihi dan membantu santri yang masih muda dengan mengajarkan dan membimbing yang berkaitan dengan materi pelajaran yang belum dikuasai baik itu kitab kuning ataupun ilmu umum.

Santri yang masih muda menghormati santri yang lebih tua mereka saling menghormati. Sebagaimana diperkuat dengan hasil dokumentasi berupa pernyataan "anti aliran islam keras(aliran sadis)" ini mengindikasikan bahwa di pesantren Ngalah menerapkan nilai pendidikan yang ramah, bukan yang marah, yang santun bukan keras, radikalime dan teroris.

\section{(4) Egaliter/kesederajaran}

Karakter kesederajatan yang menjadi kebiasaan santri di Pesantren Ngalah Pasuruan, hal ini berdasarkan pada hasil observasi pada tangga 15 Mei 2017 bahwa di dalam setiap kamar di Pesantren

${ }^{25}$ Taufiq Muhammad, Aplikasi MS. Quran In Word Kemenag, Lajnah Pentashih Mushaf al-Quran Kemenag. V.2.2. 2013 QS. al-A'raf (7): 65

${ }^{26}$ M. Quraish Shihab, Wawasan al-Qur"an, 491.

${ }_{27}^{27}$ J. Syutuhi Pulungan, Prinsip-Prinsip Pemerintahan dalam Piagam Madinab; Dintinjau dari Pandangan al-Qur'an (Cet. II; Jakarta: PT. RajaGrafindo Persada, 1996),146. 2006), 247.

${ }_{28}$ M. Quraish Shihab, Tafsir al-Misbab; Kesan, Pesan, dan Keserasian al-Qur'an, vol.13 (Cet. IV; Jakarta: Lentera Hati, 
Ngalah yang berukuran $6 \times 5 \mathrm{~m}^{2}$ rata-rata anggota kamarnya berjumlah 15 s.d 20 santri yang berasal dari latar belakang pendidikan yang berbeda, keluarga, bahasa, adat serta budaya yang berbeda. Mereka saling menghargai dan menghormati baik itu putra kiai (gus), putra pedagang, ataupun buruh tani. Mereka menggunakan dan mendapatkan fasilitas yang sama kamar tidur (ghute'an) yang sama, tidak ada yang diistimewakan. Selain itu karakter kebersamaan tercermin sikap santri pada saat mereka akan mandi, mereka menggunakan satu sabun mandi, handuk dan bahkan sabun cuci pun digunakan bersama-sama, selain itu kebersamaan di dalam mengunakan kasur tempat tidur, bantal, serta baju seragam Madrasah Diniyah. Kebersamaan tidak hanya terbatas pada penggunaan barang saja, namun pada saat kirimanpun mereka menikmati bersama-sama. ${ }^{29}$

\section{Nilai Karakter Inklusif-Pluralis ${ }^{30}$}

Nilai karakter Inklusif-pluralis (terbuka menerima perbedaan) juga dikembangkan di pesantren Ngalah. Berdasarkan hasil wawancara di atas, bahwa Pesantren Ngalah telah mengimplementasikan nilai pluralis hal ini dibuktikan pada saat penerimaan santri baru tidak membeda-bedakan status social, suku, bahasa, dari masing-masing individu santri, semuanya diterima di Pesantren Ngalah dan dibimbing serta dididik, karena sama-sama mencari ilmu, yaitu sama-sama manusianya dan sama-sama mencari ilmu.

Hal ini senada dengan Maarif menyatakan bahwa Inklusif adalah Sikap atau cara pandang terbuka yang dapat menerima perbedaan kelompok dan agama orang lain, membangun nilai-nilai kemanusiaan, melahirkan nilai baru yang modern, egaliter dan lebih mengedepankan sikap dialog dalam memecahkan permasalahan. ${ }^{31}$ Nilai Inklusif di Pesantren Ngalah merupakan sikap perwujudan dari pemahaman, keyakinan, dan pengalaman terhadap agama Islam.

Kaitannya Inklusif dengan agama menurut Shihab ada tiga langkah menuju inklusivisme agama yaitu yang pertama masing-masing kelompok agama harus memiliki kemauan mendengarkan satu sama lain tanpa harus mengorbankan prinsip-prinsip keagamaan. Kedua, masing-masing kelompok agama harus mampu melepaskan perasaan benci historis mereka dan bersama-sama terlibat dalam menganjurkan nilainilai dasar yang sama-sama dipijak oleh agama-agama tersebut. Ketiga para pemimpin agama harus menentukan bagaimana agar para pengikutnya bisa menerapkan keimanannya seraya menumbuhkan toleransi beragama yang merupakan tujuan utama yang didukung dan dimajukan oleh Negara. ${ }^{32}$

Sebagaimana menurut Gus Dur Teologi Islam yang inklusif adalah rahmatan lil ,alamin (rahmat bagi seluruh alam) teologi tersebut adalah pilar moderatisme Islam. Disini, ajaran Islam tidak diarahkan kepada eksklusifisme seperti membenci agama lain, merendahkan non-muslim, atau memusuhi dan menggunakan kekerasan dalam menyiarkan kebenaran, bahkan Islam inklusif menyiarkan toleransi beragama dan juga kerja sama.Perbedaan agama tidak menjadi penghalang untuk berinteraksi dan aksi. Sejak awal Islam selalu menganjurkan untuk merangkul non-muslim bekerjasama membangun masyarakat, maka dengan sendirinya Islam mempromosikan perdamaian bukan kekerasan. ${ }^{33}$

Senada dengan itu, Shihab menjelaskan bahwa teologi inklusif yang ada di dalam ajaran Islam menganut pada prinsip moderat. Penegakan kebenaran harusnya dilakukan dengan jalan kebenaran pula, bukan ditegakkan dengan jalan kekerasan. Kemauan untuk menghormati agama lain adalah sebagai perwujudan dari sikap moderat. Sikap moderat seperti ini tidak berarti bahwa kita tidak konsisten terhadap agama, melainkan sikap penghormatan terhadap seseorang. Semangat inklusif memiliki

\footnotetext{
${ }^{29}$ Pesantren Ngalah Pasuruan, Observasi (Pasuruan, 15 Mei 2017)

30 Yusuf, Achmad. "Strategi Pembentukan Karakter Inklusif-Pluralis Melalui Keteladanan Multikultural Kiai Di Pesantren Ngalah Pasuruan." Pendidikan Multikultural 3.1 (2019): 1-20.

${ }^{31}$ Syamsul Maarif. Pesantren Inklusif: berbasis Kearifan Lokal. Cet. I (Yogyakarta: Kaukaba, 2015) hlm. 57

32 Alwi Shihab, Islam Inklusif: Menuju Sikap Terbuka Dalam Beragama, (Bandung :Mizan, 1997), hal. 35-36.

33 Abdurrahman Wahid, Islam Kosmopolitan. hal.44.
} 
semangat mencari kebenaran dan mendialogkannya. Pantang menggunakan kekerasan dalam menegakkan kebenaran. Lebih bersikap terbuka (inklusif) dari pada keras kepala, baik dalam menerima kebenaran yang ada dalam agama non-Islam, maupun bersama-sama membangun masyarakat yang menjunjung tinggi nilai-nilai kemanusiaan. ${ }^{34}$

Pluralis dari segi bahasa, berasal dari dari kata pluralism berarti jama' atau lebih dari satu. Sedangkan dari segi istilah, sebagaimana menurut Naim pluralis tidak hanya sekedar keadaan atau fakta yang bersifat plural, jamak, atau banyak. Lebih dari itu, pluralisme secara substansional termanifestasi dalam sikap untuk saling mengakui sekaligus menghargai, menghormati, memelihara, dan bahkan mengembangkan atau memperkaya keadaan yang bersifat plural, jamak, atau banyak. ${ }^{35}$ Sementara itu Ma'arif mendefinisikan pluralisme adalah suatu sikap saling mengerti, memahami, dan menghormati adanya perbedaan-perbedaan demi tercapainya kerukunan antarumat beragama. Dalam berinteraksi dengan aneka ragam agama tersebut, umat beragama diharapkan masih memiliki komitmen yang kokoh terhadap agama masing-masing. ${ }^{36}$

Sikap pluralis dimaksud disini bukan berarti mencampuradukkan agama (sinkretsime), hal ini sebagaimana menurut Shihab pengertian pluralisme ada tiga macam : pertama, pluralisme tidak semata menunjuk pada kenyataan tentang adanya kemajemukan. Namun, yang dimaksud pluralisme adalah keterlibatan aktif terhadap kenyataan adanya kemajemukan masyarakat tersebut. Kedua, pluralisme harus dibedakan dengan kosmopolitanisme. Dalam hal ini Kosmopolitanisme menunjuk suatu realitas di mana aneka ragam ras dan bangsa hidup berdampingan di suatu lokasi. Maksudnya walaupun suatu ras dan bangsa tersebut hidup berdampingan tetapi tidak ada interksi sosial. Ketiga, konsep pluralisme tidak dapat disamakan dengan relativisme. Paham relativisme menganggap "semua agama adalah sama". Keempat, pluralisme agama bukanlah sinkretisme, yakni menciptakan suatu agama baru dengan memadukan unsur tertentu atau sebagian komponen ajaran dari beberapa agama untuk dijadikan bagian integral dari agama tersebut. ${ }^{37}$ Nilai pluralism yang ada di pesantren Ngalah merupakan suatu faham yang mengakui, menghormati, dan menyakini adanya sebuah perbedaan dan adanya keaneka ragaman ras, suku, bahasa, dan Agama yang dapat hidup berdampingan di dalam suatu entitas. ${ }^{38}$

\section{Nilai Karakter Toleransi (Tasamuh)}

Toleransi yang dalam bahasa Arabnya as-Samahah adalah konsep modern untuk menggambarkan sikap saling menghormati dan saling bekerjasama di antara kelompok-kelompok masyarakat yang berbeda baik secara etnis, bahasa, budaya, politik, maupun agama. Toleransi karena itu, merupakan konsep agung dan mulia yang sepenuhnya menjadi bagian organik dari ajaran agama-agama, termasuk agama Islam.

Karakter tasamub (toleransi) telah tertanam di dalam jiwa santri pesantren Ngalah, hal ini dibuktikan dengan sikap dan perilaku meyakini dan menghargai adanya perbedaan, baik perbedaan latar belakang sosial, budaya, agama, politik, wawasan, keyakinan, serta perbedaan dalam pandangan dan penerapan hukum fiqih yang ada di dalam fikih jawabul Masail. Adanya sikap antitoleran ini dikarenakan adanya pemahaman terhadap agama masih dangkal dan masih dianggap minim, sehingga menyebabkan sikap radikalisme agama. Manusia tidak dapat hidup tanpa orang lain, oleh sebab itu manusia disebut makhluk sosial yang saling membutuhkan satu sama lain. Lebih-lebih kita hidup dalam negara yang penuh

\footnotetext{
${ }^{34}$ Alwi Shihab, Islam Inklusif: Menuju Sikap Terbuka Dalam Beragama, (Bandung : Mizan, 1997), hal. 35-36.

${ }^{35}$ Ngainun Naim dan Achmad Sauqi, Pendidikan Multikultural Konsep dan Aplikasi, (Jogjakarta: Ar-Ruzz Media, 2008), hlm. 75

${ }^{36}$ Syamsul Ma'arif, Pendidikan Pluralisme di Indonesia, (Jogjakarta: Logung Pustaka, 2005), hlm. 17

37 Alwi Shihab, Islam Inklusif Menuju Sikeap Terbuka, hlm. 41-42

38 Yusuf, Achmad. "Strategi Pembentukan Karakter Inklusif-Pluralis Melalui Keteladanan Multikultural Kiai Di Pesantren Ngalah Pasuruan." Pendidikan Multikultural 3.1 (2019): 1-20.
} 
keragaman, baik dari segi budaya, status sosial, suku, budaya maupun agama. Untuk hidup damai dan berdampingan, tentu dibutuhkan teposeliro (tenggang rasa) atau toleransi antara satu dengan yang lainnya.

Nilai Toleransi di atas telah tertanam dan tergambar pada karakter santri Pesantren Ngalah pada ranah kognitif, afektif, dan psikomotorik santri, meliputi;

(a) Toleransi dalam Pergaulan Antar Umat Beragama

Pesantren Ngalah menyikapi toleransi dalam pergaulan antar umat beragama dari dimensi syariahnya, dengan memberikan pandangan hukum toleransi dalam pergaulan antar umat beragama (pluralitas agama) dengan hukum boleh, bergaul atau menjalin hubungan baik dalam urusan dunia saja dengan sebatas dhohir, dan tidak dilarang, (bahkan dianjurkan) apabila bertujuan untuk menghindari bahaya yang berasal dari mereka atau untuk memperoleh kemanfaatan atau kemaslahatan. Hal ini berdasarkan pada kitab Tafsir Munir Lin Nawawi juz 1, hal. 94. kitab al-Bab Fii 'Ulum al-Kitab bab surat Ali Imran juz 5 hal.143. dan dalam Hasyiyah al-Bujairami 'ala al-Khatib pada Fasal Fii al-Jizyah juz 4 halaman 291-292:

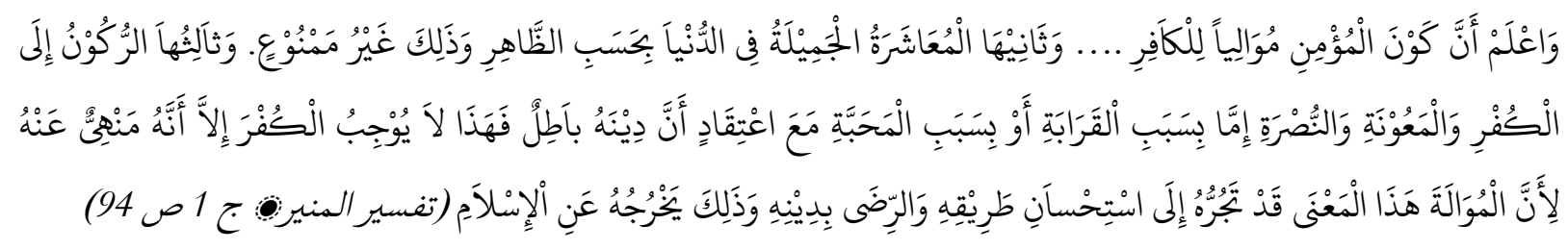

Keterangan Hasyiyah al-Bujairami 'ala al-Khatib pada Fasal Fii al-Jizyah, sebagai berikut:

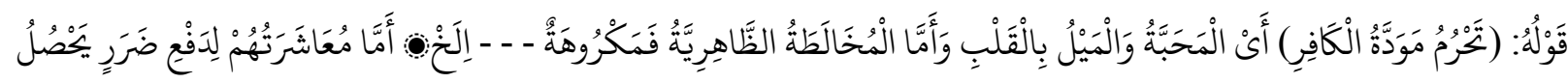

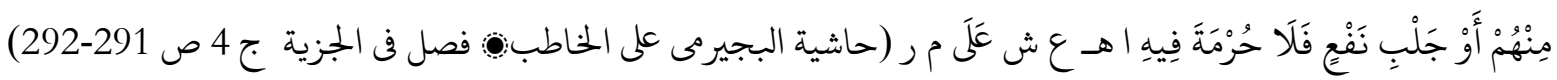

Kata pengarang, "Haram mencintai non muslim" maksudnya, cinta, senang dan condong dengan hati. Adapun berinteraksi dengan orang-non muslim dalam urusan zhahir adalah makruh, sedangkan berinteraksi dengan mereka untuk menghindari bahaya yang berasal dari mereka atau untuk memperoleh manfaat maka tidak dilarang. (Hasyiyah alBujairami 'ala al-Khatib pada Fasal Fii al-Jizyah, juz 4, hal. 291-292).

(b) Mengucapkan Salam Kepada Non Muslim ${ }^{39}$

Sikap toleransi yang selanjutnya adalah mengucapkan salam kepada non muslim, pesantren Ngalah menyikapi dengan memberikan pandangan hukum boleh mengucapkan salam kepada non muslim, hal ini berdasar pada al-Majmu' Syarh al-Muhadzdzab, juz 4, hal. 507 ;

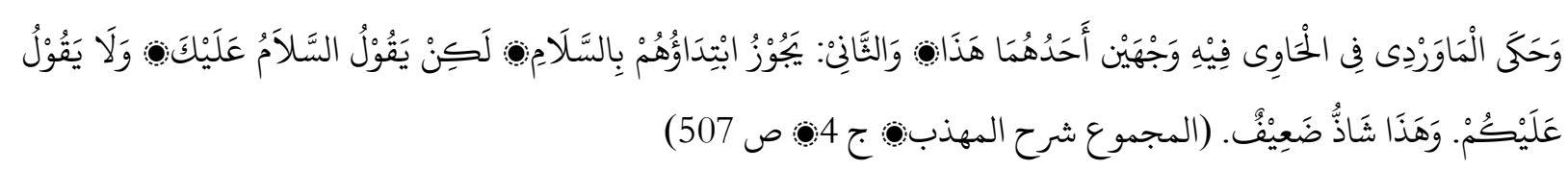

Dalam kitab Hawy Imam Mawardi menceritakan bahwa memberi salam kepada orang non muslim ada dua macam: yang pertama tidak boleh, kedua: boleh memberi salam kepada orang non muslim, akan tetapi dengan mengucapkan as-Salamu 'Alaika. Jangan mengucapkan as-Salamu 'alaikum. Pendapat ini lemah dan langka. (al-Majmu' Syarh al-Muhadzdzab, juz 4, hal. 507)

39 non muslim adalah orang yang bukan beragama Islam termasuk orang Yahudi, Nasrani, Kristen, Katholik, Hindu, Budha, Konghucu dan lain-lain 


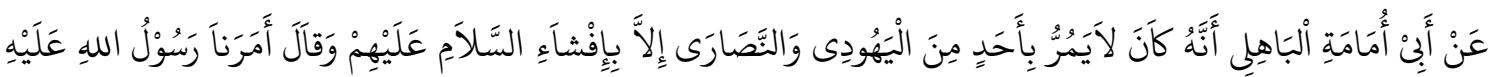

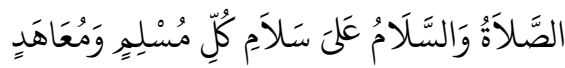

Diceritakan dari Abi Umamah al-Bahali, sesunggubnya dia tidak pernah berjalan bertemu orang yabudi kecuali dengan memberi salam kepada mereka. Abu Umamah berkata: Rasulullah memerintah kepada kita supaya menebar salam kepada setiap orang Islam dan orang kafir mu'ahad (orang kafir yang berjanji kepada pemerintah akan tunduk dan patuh pada undang-undang Negara).

(c) Non muslim Masuk ke Dalam Masjid

Pesantren Ngalah yang sering kali menjadi tujuan kunjungan para tokoh non muslim dan lintas agama baik itu pendeta, romo, uskup, biarawati dan lain sebagainya. Ketika berada di Ponpes para tamu itu oleh sang Kyai Ngalah diajak mengikuti suatu acara (pengajian seninan, pengajian selosoan, pengajian tafsir dan berdoa) bersama-sama masyarakat di dalam masjid.

Kaitannya dengan dengan hal di atas, Pesantren ngalah juga memberikan wawasan tentang hukum non muslim masuk ke dalam masjid dan berdiam di dalamnya secara mutlak adalah boleh, dengan syarat bisa menjaga kehormatan masjid. Hal ini dijelaskan dalam kitab al-Kurdii 'ala al-Minhaj al-Qawim, halaman 98. Dan dalam kitab Busyra al-Kariim juz 1 halaman 37:

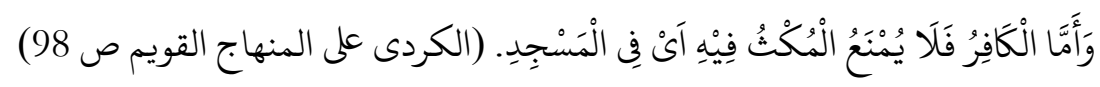

Adapun orang-orang non muslim tidak dilarang diam di dalam masjid. (al-Kurdii 'ala al-Minhaj alQawim, hal. 98)

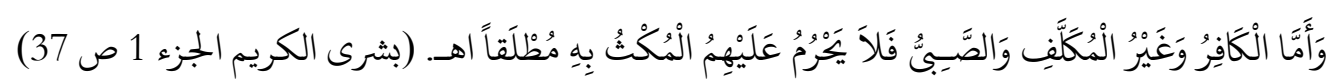

Adapun orang-orang nonmuslim, orangyang tidak mukallaf dan bocah, tidak haram diam di dalam masjid secara mutlak. (Busyra al-Karim, juz 1, hal. 37)

Lebih lanjut, dalam kitab al-Majmu' pengikut Imam Syafi'i (ulama' madzhab Syafi'iyah) berpendapat; bahwa orang nonmuslim boleh masuk bahkan menginap di dalam masjid (kecuali Masjidil Haram Makah), dengan seizin kaum muslimin;

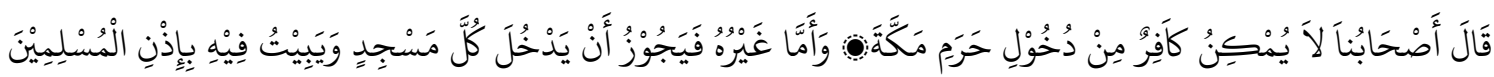

$$
\begin{aligned}
& \text { وَيْمنَعُ مِنْهُ بِغَيْرِ إذْنٍ (المجموع شرح المهذب جر }
\end{aligned}
$$

Menurut Ashbabuna (pengikut Imam Syafii) bahwa orang nonmuslim tidak diperbolebkan memasuki tanah haram Mekah, adapun masuk dan menginap di masjid selain tanah haram Mekekah diperbolebkan dengan iæin kaum muslimin, dan dilarang jika tanpa ada iæin”. (al-Majmu' Syarah al-Muhadzab, juz 2, hal. 198)

Berdasarkan pada uraian di atas, bahwa karakter toleransi di Pesantren Ngalah ini berimplikasi terhadap karakter santri di dalam bergaul dan berinteraksi dengan sesama santri yang lainnya yang berbeda latar belakang dengan penuh penghormatan, dan saling menghargai. Disamping itu adanya sikap santri di dalam menjamu tamu yang datang ke pesantren Ngalah baik itu muslim, atau non muslim seperti kedatangan tamu Biarawati ke Pesantren Ngalah, mereka penuh antusiasme dan bersemangat di dalam menyambut dan mengantarkan berkeliling ke area Pesantren untuk melihat proses pembelajaran madrasah diniyah, selain itu santri yang ada di madrasah diniyah pun antusiasme 
di dalam menerima kunjungan para biarawati dengan tanpa adanya rasa canggung, bahkan foto bersama. ${ }^{40}$

Berdasarkan paparan di atas, bahwa toleransi yang di kembangkan Pesantren Ngalah di dalam konteks relasi antar umat beragama bertujuan agar terjalin kerukunan, kerharmonisan, dan kebersamaan antar pemeluk agama dalam bingkai Bhinneka Tunggal Ika, serta menguatkan integritas bangsa dari kecaman-kecaman eksternal. Sebagaimana ungkapan Kiai sebagai salah satu alasan pesantren Ngalah dekat dengan non muslim, karena pesantren Ngalah bukan sarang teoris. Selain itu pergaulan antara pesantren Ngalah (sebagai cerminan islam yang ramah) dengan non muslim diibaratkan seperti "mur dan baut" yang berperan dan berfungsi untuk saling menjaga, menguatkan atau merapatkan NKRI.

Namun disisi lain kedekatan pesantren Ngalah dengan Non Muslim menimbulkan banyak kecaman dari berbagai pihak. Seperti halnya dalam aktivitas doa bersama dengan non muslim di Tutur Pasuruan pada acara rutinan Drikrul Ghofilin, kegiatan tersebut diasumsikan bahwa pesantren Ngalah telah mengadakan pendangkalan Akidah Islam, proses pengkafiran, serta urup-urupan (ijol-ijolan agama) sehingga kegiatan tersebut haram. MUI Tutur telah melaporkan kiai Sholeh melakukan pendangkalan agama dan perusakan aqidah modusnya melalui qikerul ghofilin diakhiri dengan doa lintas agama yakni pendeta, biksu masuk masjid doa bersama bergantian dengan kyai. Dengan adanya laporan tersebut kiai Sholeh menjawabnya melalui pengajian rutinan khususiyah Selasa memperbanyak dan melanggengkan zikir sirri menyebut asma Allah di dalam qolb pada setiap gerak langkah dan nafas seperti yang telah diajarkan dalam tarekat. Apabila hal ini dilakukan maka, bukan lagi pendangkalan akidah yang terjadi akan tetapi sebaliknya, lebih beraqidah dan benar beragamanya.

Seringkali kiai Sholeh memberikan penjelasan kepada para jama'ahnya apabila ingin mengetahui kepribadian sekaligus ajaran yang dikembangkan kiai Sholeh di pondok pesantren yakni harus dengan dua kacamata yakni, menggunakan kacamata syari'at dan tarekat, karena seringkali orang tertipu dan salah paham terhadap apa yang sudah dilakukannya. Apabila orang luar melihat dari satu kacamata saja maka bisa dipastikan akan keliru dan ujung-ujungnya pasti menyalahkan.

Dalam konteks toleransi antar-umat beragama, Islam memiliki konsep yang jelas. "Tidak ada paksaan dalam agama", "Bagi kalian agama kalian, dan bagi kami agama kami"41 adalah contoh populer dari toleransi dalam Islam. Selain ayat-ayat itu, banyak ayat lain yang tersebar di berbagai Surah. Juga sejumlah hadis dan praktik toleransi dalam sejarah Islam. Fakta-fakta historis itu menunjukkan bahwa masalah toleransi dalam Islam bukanlah konsep asing.

Menurut ajaran Islam, toleransi bukan saja terhadap sesama manusia, tetapi juga terhadap alam semesta, binatang, dan lingkungan hidup. Dengan makna toleransi yang luas semacam ini, maka toleransi antar-umat beragam dalam islam memperoleh perhatian penting dan serius. Apalagi toleransi beragama adalah masalah yang menyangkut eksistensi keyakinan manusia terhadap Allah. Ia begitu sensitif, primordial, dan mudah membakar konflik sehingga menyedot perhatian besar dari Islam.

Hadits Nabi tentang persaudaraan universal juga menyatakan, "irhamun man fil ardhi yarhamukum man fil sam $\vec{a}$ ' (sayangilah orang yang ada di bumi maka akan sayang pula kepadamu mereka yang di langit). Persaudaraan universal adalah bentuk dari toleransi yang diajarkan Islam. Persaudaraan ini menyebabkan terlindunginya hak-hak orang lain dan diterimanya perbedaan dalam suatu masyarakat Islam. Dalam persaudaraan universal juga terlibat konsep keadilan, perdamaian, dan kerja sama yang

40 Pesantren Ngalah, Observasi. (Pasuruan, diambil 18 Oktober 2017) 
saling menguntungkan serta menegasikan semua keburukan. Adannya sikap toleran ini Islam di sebut sebagai agama kasih sayang. Sikap toleran di dalam Islam disini lebih pada hubungan antara muslim dan non muslim sebagaimana QS. Ali Imron ayat $159^{42}$;

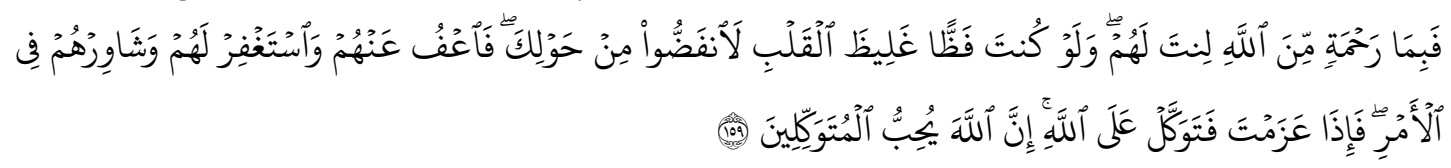

Selain itu karakter toleransi telah dikembangkan di Pesantren Ngalah Pasuruan, sebagai hasil dokumentasi di dalam Pedoman Santri sebagai berikut;

"Kami menyuruh santri untuk menyusun buku "Pedoman Santri" dan menterjemahkan sirah an-Nabawiyah halaman 31-35 jus III atau disebut Mitsaqul Madinah atau Piagam Madinah, dengan harapan hal ini bias menjadi acuan dan pembuktian dasar Negara kita yaitu Pancasila dan UUD 45 itu sudah sesuai dengan nilai-nilai ajaran Islam sekaligus untuk lebih memantabkan dalam pengamalannya, karena hal itu mengacu pada masa pemerintahan Rosulullah SAW yang bukan berbentuk Negara Islam terbukti dengan adanya Piagam Madinah Ini." 43

berdasarkan pada hasil dokumentasi di atas, yang ditulis pada halaman awal buku pedoman santri maka selain membentuk karakter Pancasilais, secara inheren pesantren Ngalah juga membentuk dan membiasakan nilai toleransi dengan bentuk sikap menerima dan menghargai perbedaan, toleransi, serta mencintai NKRI, selain itu yang lebih ditekankan adalah pemahaman santri agar tidak memiliki radikalisme agama apalagi mengikuti dan mendirikan Negara Islam (Khilafah) karena Indonesia terdiri dari beragam suku, bahasa, agama, dan budaya. Sebagai bentuk upaya dalam memberikan wawasan kepada santri bahwa pancasila tidak terlepas dari agama, karena nilai-nilai agama secara universal tercermin dalam Pancasila Santri ditugaskan untuk mengkaji pancasila serta mencantumkan dasar ayat al-Qur'annya sebagai langkah. Selain itu, Santri menyusun khutbah dengan judul koleksi khutbah ala pesantren Ngalah cerminan nilai kedamaian edisi I, II, dan III (2007-2011). Isi khutbah tersebut memuat tema yang mencerminkan nilai-nilai kedamaian, toleransi, tolong menolong, saling mengenal dan saling berdampingan dalam bermasyarakat. Misalnya indahnya keragaman, Islam agama damai, rukun dan damai dalam perbedaan. ${ }^{44}$ hal ini senada dengan Agustian yang dikutip Ghony bahwa karakter yang dapat di kembangkan pada aspek nilai dalam kehidupan bermasyarakat yaitu berupa toleransi, solidaritas, empati, musyawarah, egaliter, keterbukaan, keadilan, dan kerjasama ${ }^{45}$ kasih sayang, nasionalisme, prasangka baik, saling percaya, percaya diri, tanggung jawab, kejujuran, ketulusan, amanah. ${ }^{46}$ Demokrasi, kesetaraan, keadilan, kemanusiaan, kebersamaan, kedamaian, Sikap Mengakui, Menerima, dan Menghargai Keragaman. ${ }^{47}$ at Taaruf, at Tawassuth, at Tasaamuh, at Taawun, dan at Tawazun ${ }^{48}$.

42 Aplikasi MS. Quran In Word Kemenag, Lajnah Pentashih Mushaf al-Quran Kemenag. V.2.2. 2013. QS. Ali Imron

${ }^{43}$ Santri Mallimin Muallimat, Buku Pedoman Santri Darut Taqwa dalam Berbangsa dan Bernegara: Sebagai Rujukan Kebidupan Berbangsa dan Bernegara. Edisi Revisi. (Pasuruan, YudhartaAdvertising,tt), hal iii.

${ }^{44}$ Santri Ngalah, Koleksi Khutbah Ala Pesantren Ngalab Cerminan Nilai Kedamaian.(Pasuruan, Ponpes Ngalah, 2011)

${ }^{45}$ Lihat Murniati Agustian dan Yustina Rostiawati. Pendidikan Multikultural Sekolah Menengah Atas. (Jakarta: Univ. Atmajaya, 2008),hlm.11.

${ }^{46}$ Lihat hasil lokakarya implementasi Pendidikan Multikultural, Grand Media Jakarta, 10-13 April 2008 yang diselenggarakan oleh Departemen Agama RI.

${ }^{47}$ Abdullah Aly, Pendidikan Islam Multikultural di Pondok Pesantren, Telaah terbadap Kurikulum Pondok Pesantren Modern Islam Assalam Surakart, Yogyakarta: Pustaka Pelajar, 2011, hlm. 109

${ }^{48}$ Muhammad Tolchah Hasan. Pendidikan Multikultural: Sebagai Opsi Penanggulangan Terorisme. Malang: Lembaga Penerbitan UNISMA.2016. hlm. 63 
Best practices nilai toleransi di pesantren Ngalah Pasuruan di atas adalah meyakini dan menghargai terhadap adanya perbedaan. Baik perbedaan dari aspek latar belakang sosial, budaya, agama, politik, wawasan, serta perbedaan dalam hukum fiqih. Berdasarkan hasil observasi dalam proses implementasi nilai toleransi di pondok Pesantren Ngalah dapat diungkap bahwa pesantren Ngalah telah memberikan peranan dan sumbangsih kepada masyarakat pesantren Ngalah secara khusus, dan pada masyakarat secara luas pada umumnya berupa pemahaman wawasan nilai-nilai multikultural yang di dalamnya terdapat nilai toleransi yang dapat dijadikan best practices pada semua lini lapisan masyarakat agar dapat hidup berdampingan, penuh kedamaian, saling menghargai, menghormati, serta saling menerima walaupun memiliki latar belakang berbeda. ${ }^{49}$

Hal ini sesuai dengan konsep toleransi di dalam Islam sebagaimana menurut Hasan bahwa adanaya sikap saling menghormati, saling bekerjasama, diantara kelompok-kelompok masyarakat yang berbeda etnis, bahasa, budaya, wawasan politik, maupun berbeda keyakinan. Lebih lanjut toleransi merupakan konsep agung dan mulia yang sepenuhnya menjadi bagian organic dari ajaran agama Islam.

Toleransi dalam islam kaitannya dengan antar umat beragama memiliki konsep yang jelas " tidak ada paksaan di dalam beragama" lebih lanjut "bagi kalian agama kalian dan bagiku agamaku, ini membuktikan bahwa pemberlakuan toleransi (tasamub) telah ada dan dilakukan di dalam Islam.

Pemberlakuan konsep toleransi di dalam Islam sebagaimana menurut Hasan sebagai berikut;

Pertama, keyakinan umat Islam bahwa manusia itu adalah makhluk yang mulia apapun agama, kebangsaan, ras, bahasa, dan warna kulitnya, hal ini dipertegas al-Qur'an surat al-Isro ${ }^{50}$ ayat 70 sebagai berikut;

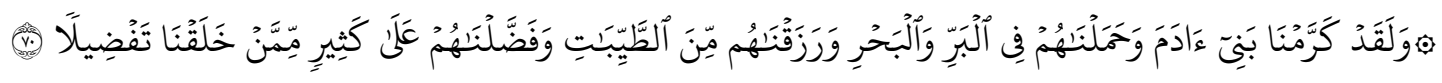

Ayat ini menjelaskan bahwa kemuliaan yang diberikan oleh Allah kepada manusia ini mengindikasikan bahwa setiap manusia memiliki hak untuk dihormati, dihargai dan dilindungi. Lebih lanjut sebagaimana bentuk toleransi yang dilakukan oleh Nabi Muhammad SAW ketika ada jenazah yang dibawa lewat depan Nabi Muhammad SAW lalu Nabi berdiri sebagai bentuk penghormatan kepada jenazah tersebut, kemudian ada salah satu sahabat yang memberitahukan kepada Nabi bahwa yang meninggal itu adalah orang Yahudi, namun Jawaban Nabi dengan nada bertanya "bukankah dia juga manusia?"

Kedua, keyakinan umat islam bahwa perbedaan manusia dalam memeluk agama adalah karena kehendak Allah (sunnatullab) yang dalam hal islam telah memberikan kebebasan kepada makhluknya untuk melakukan atau meninggalkannya. Hal ini berdasar pada al-Qur'an surat Huud $^{51}$ ayat 118 sebagai berikut;

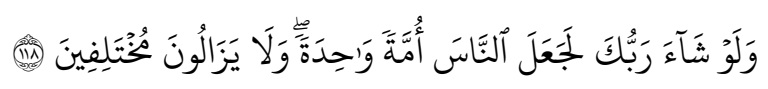

Ketiga, orang islam tidak diberikan tugas untuk menghisab orang kafir, karena kekufurannya, persoalan ini bukan menjadi tugas orang muslim, karena itu adalah hak prerogative Allah SWT.

Keempat, keimanan orang muslim bahwa Allah menyuruh berlaku adil dan menyukai perbuatan adil serta menyerukan akhlak mulai sekalipun kepada kaum kafir, dan membenci kedholiman meskipun yang melakukan kedholiman itu orang muslim terhadap orang non muslim.

\footnotetext{
49 Observasi di Pesantren Ngalah, diambil 04 Juni 2017

${ }^{50}$ Aplikasi MS. Qur'an in Word Kemenag, Lajnah Pentashih Mushaf al-Qur'an Kemenag. V2.2 2013. QS. al-Isra 70.

51 Aplikasi MS. Qur'an in Word Kemenag, Lajnah Pentashih Mushaf al-Qur'an Kemenag. V2.2 2013. QS. Huud:118.
} 
Kelima, ajaran islam tidak pernah memaksa umat lain untuk menjadi muslim apalagi melalui jalan kekerasan.

\section{Nilai Karakter Luwas dan Luwes}

Luwas dan luwes turunan dari nilai toleransi yang dikembangkan di Pesantren Ngalah. Nilai luwas dan luwes di pesantren Ngalah dikembangkan pada dimensi social sebagaimana di dalam penerapan hukum fikih. Moderat disini bukan berarti tidak memiliki prinsip, namun bersifat dinamis, atau fleksibel yang disesuaikan dengan kondisi dan situasi tertentu dalam menerapkan hukum. Berdasarkan pada hasil pengamatan bahwa nilai luwas tercermin pada sikap santri di dalam berpandangan dan berwawasan keilmuan yangbanyak dan mendalam, baik keilmuan duniawi (umum) ${ }^{52}$ ilmu ukhrowi ${ }^{53}$ (diniyah) serta ilmu sosial kemasyarakatan ${ }^{54}$.

Sedangkan nilai luwes tercermin pada sikap dan tindakan santri di dalam menghadapi permasalahan-permasalahan sosial kemasyarakatan dimensi Ubudiyah, muamalah, budaya, dan sosial politik dengan sikap yang bijaksana, ramah, santun, tidak mudah menyalahkan bahkan mengkafirkan orang lain yang tidak sefaham atau tidak sama dengan pandangannya, dengan tetap memegang prinsip-prinsip yang mengacu pada akar nilai-nilai inklusif menurut Hasan menurut yaitu taaruf, tasamuh, tawazun, tawasuth dan taawun, ${ }^{55}$ serta mengedepankan nilai-nilai manusiawi. Pembiasaan sikap luwes ini dilakukan dengan menugaskan penyusunan buku Fikih Galak Gampil dan Jawabul Masail yang di dalamnya terkandung dengan nilai-nilai tasamub terhadap para imam Mujtahid serta kepada penganutnya yang berbeda pandangan hukum.

\section{Nilai Karakter Demokratis}

Karakter demokratis yang merupakan ide atau atau pandangan hidup yang mengutamakan persamaan hak dan kewajiban serta perlakuan yang sama bagi semua warga Negara. Menurut Ubaidillah demokrasi adalah kekuasaan atau kedaulatan rakyat, kekuasaan tertinggi berada dalam keputusan rakyat, rakyat berkuasa, pemerintahan rakyat dan kekuasaan oleh rakyat ${ }^{56}$ Demokrasi merupakan sikap kebebasan dalam mengambil sebuah keputusan pribadi baik bertujuan individu ataupun khalayak umum yang disertai penuh tanggung jawab yang diwujudkan dengan adanya pengakuan atas hak asasi manusia bagi setiap individu. Karakter demokrasi di Pesantren Ngalah telah dikembangkan hal ini tergambar pada aktivitas santri yang diberikan keleluawasaan dan kebebasan di dalam memilih kamar tempat santri baru untuk di tempati, walaupun secara ketentuan telah ada, namun adanya kebebasan santri di dalam memilih kamar bagi santri ini lebih mengutamakan pada keinginan santri dengan tujuan agar santri merasa betah atau kerasan lebih dahulu di Pesantren Ngalah.

Selain itu, berdasarkan pengamatan di asrama, meskipun pesantren ini lebih kental berbasis kultural, namun lebih mengedapankan nilai-nilai demokrasi di dalam penentuan ketua kamar, dan pengurus asrama, semuanya dipilih oleh anggota asrama. Hal ini sebagaimana dibuktikan di asrama I, nilai kebebasan di Pesantren Ngalah adalah tercermin pada saat adanya penentuan

\footnotetext{
${ }^{52}$ Santri pesantren Ngalah mengikuti pendidikan mulai dari tingkat SLTP-Perguruan Tinggi

${ }^{53}$ Santri mengikuti pendidikan Madrasah Diniyah mulai dari Ibtidaiyah sampai muallimin-muallimat

${ }^{54}$ Santri dilibatkan secara langsung di dalam berinteraksi dengan masyakarat melalui kegiatan-kegiatan rutinan Pesantren meliputi: dibaan baersama masyarakat, manaqiban dan dzikrul ghofilin yang dilebih pada tataran praktik di lapangan.

55 Muhammad Tolchah Hasan. Pendidikan Multikultural: Sebagai Opsi Penanggulangan Terorisme. Malang: Lembaga Penerbitan UNISMA.2016. hlm. 63

56 A. Ubaidillah, dkk., Pendidikan Kewargaan Demokrasi, HAM, dan Masyarakat Madani, (Jakarta: IAIN Jakarta Press, 2000), hlm. 162
} 
kepengurusan asrama. Meskipun pesantren yang notabenenya adalah berbasis kultural, namun cerminan sikap demokrasi santri ini dapat berjalan dengan kondusif.

Dalam proses penentuan pengurus asrama ini menggunakan sistem demokrasi seperti di dalam pemilihan kepala Daerah, Gubernur dan Presiden. Hal ini telah sesuai dengan karakter demokrasi yang dikembangkan oleh Kemendikbud yaitu Cara berfikir, bersikap dan bertindak yang menilai sama hak dan kewajibannya dengan orang lain. ${ }^{57} \mathrm{Hal}$ ini sebagaimana diperkuat oleh hasil wawancara dengan pengurus Putri sebagai berikut;

"proses pemilihan kepala asrama yang telah dilaksanakan biasanya sama dengan system pemilu, yaitu ada calonnya yang ditentukan oleh pengurus kemudian diajukan ke pengasuh asrama, kalau sudah sesuai ketentuannya maka yang menentukan adalah santri asrama/warga asrama tersebut melalui pemilihan sebagaimana pemilihan presiden, Gubernur dan kepala Daerah",58

Lebih lanjut nilai demokrasi dilihat lebih luas, di Pesantren Ngalah tercermin pada saat adanya pemilihan PILKADA, PILGUB, dan PILPRES melalui pencoblosan partai politik sesuai dengan keinginan santri atau santri mengikuti orang tuanya, bukan ditentukan oleh pengurus untuk memilih pasangan calon tertentu, namun diberikan kebebasan yang seluas-luasnya untuk memilih parpol seperti PKB, PDIP, GOLKAR, PPP, GERINDRA, HANURA, DEMOKRAT, NASDEM, asalkan partai politik tersebut berasaskan Pancasila, dan tidak terjadi pertengkaran, permusuhan sesama santri. Lebih lanjut Kiai dalam hal ini memberikan intruksi kepada putranya agar tidak mengikuti dan menjadi calon di partai politik, agar tidak berebut tempat -rebutandengan santri dan wali santri, karena itu bukan zonanya, itu adalah wilayahnya santri dan wali santri, serta (jamaah) masyarakat. ${ }^{59}$

Nilai demokrasi ini mengindikasikan bahwa pendidikan multikultural telah dimplementasikan di Pesantren Ngalah, hal ini sesuai dengan pendapatnya Aly bahwa” prinsipprinsip pendidikan multikultural memiliki karakteristik demokrasi, kesetaraan, dan keadilan lebih lanjut menyatakan bahwa prinsip-prinsip ini sejalan dengan program UNESCO tentang education for all yaitu program pendidikan yang memberikan peluang yang sama kepada semua anak untuk memperoleh pendidikan." ${ }^{, 0}$

Dalam perspektif Islam, nilai demokrasi yang merupakan karakteristik pendidikan multikultural ${ }^{61}$ juga memiliki relevansi dengan ayat-ayat al-Quran, sebagaimana menurut Lathif prinsip-prinsip demokrasi, kesetaraan, dan keadilan tercantum di dalam QS. al-Syura ayat 38, alHadid 25, dan al-A'raf ayat 181 lebih lanjut Ibrahim menyatakan bahwa di dalam al-Quran telah disebutkan dan memberikan landasan moral dan etik bahwa setiap individu-tanpa terkecuali-memiliki hak untuk mendapatkan keadilan, baik ucapan, sikap, maupun perbuatan. ${ }^{62}$ Perlakuan adil disini telah dicontohkan oleh Nabi Muhammad SAW adalah dalam bentuk interaksi sosial

${ }^{57}$ Kemendiknas,

Pendidikan

Karakter

bangsa,

dalam

perpustakaan.kemdiknas.go.id/download/Pendidikan\%20Karakter.pdf

${ }^{58}$ Dewi, wancara. (Sengonagung, 27 Juli 2017)

${ }^{59}$ Yasir Arafat. Wawancara. (Purwosari, 30 Mei 2017)

${ }^{60}$ Abdullah Aly, Pendidikan Islam Multikultural di Pesantren: Telaab terbadap Kurikulum Pondok Pesantren Modern Islam

Assalam Surakarta. (Yogyakarta: Pustaka Pelajar, 2011) hlm. 110

${ }^{61}$ Abdullah Aly, Pendidikan Islam Multikultural di..................hlm. 110

62 Abdul Lathif Ibn Ibrahiim Ibn Abdul Lathiif al-Husain. Tasamub al Ghorb Maal Muslimiin fi Asr wa al-hadir. (Riyadh: Dar Ibn al-Jauzi, 1999), hlm. 45. lihat juga Abdullah Aly, Pendidikan Islam Multikultural di .......hlm. 111 
baik itu muslim dengan sesama muslim, atau muslim dengan non muslim, selain itu interaksi sosial antara orang Arab dengan selain Arab, orang kulit putih dengan orang kulit hitam. ${ }^{63}$

Senada dengan hal tersebut, menurut Aly Islam telah memberikan contoh bahkan doktrin tentang prinsip demokrasi, kesetaraan, dan keadilan sebagaimana telah di praktikan oleh Nabi Muhamad SAW untuk mengelola keragaman kelompok dalam masyarakat Madinah yang memiliki keragaman ras, budaya, suku, dan agama. ${ }^{64}$

\section{Nilai Karakter Nasionalis}

Kata nation berasal dari kata nascie yang memiliki arti dilahirkan. Jadi kata nation merupakan bangsa yang dipersatukan karena adanya sebab kelahiran. Sedangkan dari sisi antropologis dan sosiologis, Yatim berpendapat bahwa nation (bangsa) adalah suatu persekutuan hidup yang berdiri sendiri dan masing-masing anggota persekutuan hidup tersebut merasa memiliki satu kesatuan ras, bahasa, agama, sejarah dan adat-istiadat. ${ }^{65}$ Lebih lanjut menurut Stoddard "Nasionalisme adalah suatu keadaan jiwa, suatu kepercayaan yang dianut oleh sejumlah besar manusia sehingga mereka membentuk suatu kebangsaan dalam bentuk kebersamaan" "66 Sedangkan Menurut Ensiklopedi Nasional Indonesia, Nasionalisme adalah paham kebangsaan yang tumbuh karena adanya persamaan nasib dan sejarah serta kepentingan untuk hidup bersama sebagai suatu bangsa yang merdeka, bersatu, berdaulat, demokratis dan maju dalam satu kesatuan bangsa dan negara serta cita-cita bersama guna mencapai, memelihara dan mengabdi identitas, persatuan, kemakmuran dan kekuatan atau kekuasaan negara bangsa yang bersangkutan. ${ }^{67}$ Sedangkan Nasionalis sebagaimana menurut Mustari adalah "cara berpikir, bersikap dan berbuat yang menunjukkan kesetiaan, kepedulian, dan penghargaan yang tinggi terhadap bahasa, lingkungan fisik, social, budaya, ekonomi dan politik bangsanya" ${ }^{6}$

Nilai karakter nasionalis dalam bentuk kegiatan santri merayakan proklamasi kemerdekaan HUT RI ke 72, Lebih lanjut berdasarkan hasil wawancara dengan SQ kepala Asrama F sebagai berikut;

"Pesantren Ngalah dalam merayakan dan mengisi proklamasi kemerdekaan RI ke 72 semua santri Pesantren Ngalah mengisi dengan dua agenda yang pertama dimensi Ritual, dan Dimensi Sosial. Ritual yaitu santri melakukan doa bersama dengan Banser di Masjid Aminah. Bertujuan mendoakan para pahlawan kemerdekaan RI yang telah gugur. Dimensi Sosialnya diisi dengan acara lomba-lomba seperti balap karung, lomba, fun games, kerupuk sambal, topi kukuruyuk, tebak kata, temple gambar pahlawan, sedangkan lomba yang dilaksanakan di Asrama Putri adalah lomba pidato, lomba sholawat, lomba pembacaan teks proklamasi, lomba Paduan Suara. semua ini dilakukan untuk mengisi dan mengenang jasa para pahlawan, dan agar santri memiliki jiwa pancasilais sesuai dengan dawuh Romo Kiai" ${ }^{\prime 9}$

${ }^{63}$ J. Suyuti Pulungan. Prinsip-prinsip Pemerintahan di dalam Piagam Madinah ditinjau dari Pandangan al-Qur'an (Jakarta: Raja Grafindo Persada, 1996) hlm. 152 lihat juga Abdullah al Habsyi, Hak-Hak. Sipil dalam Islam: Tinjauan Kritis. Tekstual dan Kontekstual atas Tradsisi Ablul Bait (Jakarta; al-Huda, 2004) hlm. 23.

64 Abdullah Aly, Pendidiken Islam Multikultural di ............hlm. 113

${ }^{65}$ Badri Yatim, Soekarno Islam dan Nasionalisme (Jakarta: PT. Logos Wacana Ilmu, 1999), hlm. 57. Lihat juga Mohamad Mustari, Nilai Karakter Refleksi untuk. Pendidikan Karakter....hlm. 190.

${ }^{66}$ Badri Yatim, Soekarno Islam dan Nasionalisme..hlm. 57

${ }^{67}$ Departemen Pendidikan RI, Ensiklopedi Nasional Indonesia, (Jakarta: PT. Cipta Adi Pustaka, 1990), Jilid 11, hlm. 31

${ }^{68}$ Mohamad Mustari, Nilai Karakter Refleksi untuk Pendidikan Karakter. (Yogyakarta: LaskBang PRESSindo. 2015), hlm

${ }^{69}$ Syifaul Qulub, Wawancara, (Kantor Madrasah Diniyah, Sabtu, 19 Agustus 2017) 
aktivitas yang dilakukan santri Pesantren Ngalah yang bermuatan pada nilai-nilai pancasilais yaitu adanya karakter atau sikap mengikuti perayaan dan kegiatan yang diselenggarakan Pesantren Ngalah sebagai bentuk dalam mengenang jasa-jasa para pahlawan, serta menghargai dan menjaga hasil jerih payah para pahlawan kemerdekaan RI yang telah gugur di medan pertempuan di dalam memperjuangkan kemerdekaan bangsa Indonesia. Kegiatan yang dilakukan di Pesantren Ngalah ini terdiri dari dua jenis kegiatan yaitu dimensi ritual dan sosial.

Hal ini diperkuat dengan adanya maklumat Kiai yang dipasang pada dinding di depan kantor pusat;

"Negara Indonesia terdiri dari berbagai pulau, suku, seni, budaya bahasa, dan agama yang berbeda-beda. Perbedaan tersebut merupakan satu kesatuan dalam bingkai Negara Kesatuan Rebuplik Indonesia yang berasaskan Pancasila dan UUD 1945. Namun ada sebagian kelompok atau golongan yang menginginkan dan melakukan upaya untuk merubah Dasar Negara Indonesia yang kita cintai ini dengan bentuk Negara Islam. Adanya upaya dari golongan atau kelompok yang berkeinginan untuk merubah terhadap dasar-dasar Negara Indonesia tersebut. Kami secara tegas mengambil sikap untuk tidak setuju kalau negara Indonesia ini dijadikan Negara yang berbentuk Negara Islam.

Dengan alasan :

1. Pancasila itu sudah sesuai dengan al-Qur'an

2. Rosulullah sendiri tidak pernah membentuk sistem Negara Islam (baca:Piagam Madinah)

3. Golongan atau kelompok tersebut dinilai:

a. Tidak menghargai bahkan menghianati para pejuang Kemerdekaan bangsa Indonesia

b. Berusaha memecah belah rakyat Indonesia dengan merusak tatanan atau sistem Negara Indonesia bahkan berusaha menghancurkan bangunan Negara Kesatuan Republik Indonesia (NKRI)

c. Akan terjadi pergeseran tatanan nilai-nilai tradisi atau kultur islam ala NU." 70

Berdasarkan maklumat di atas, bahwa karakter nasionalis yang ditanamkan ditanamkan Pesantren Ngalah kepada santri adalah nilai semangat kebangsaan karena bangsa Indonesia ini merupakan Negara yang majemuk, beragam suku, bahasa bangsa dan agama, serta Negara Indonesia ini merupakan Negara Kesatuan Republik Indonesia (NKRI) sehingga nilai ini ditanamkan kepada santri dengan bertujuan "agar tidak lupa dengan rumah sendiri, agar tidak berjalan di tempat, agar mempunyai wawasan yang luas dan luwes".

Narasi di atas sesuai dengan pernyataan Kartodirjo tentang nilai nasionalisme, meliputi: (1) kesatuan (unity); (2) kebebasan (liberty); (3) kesamaan (equality); (4) kepribadian (individuality) dan (5) prestasi (performance). ${ }^{71}$ Senada dengan di atas, Moesa dalam penelitiannya menyatakan bahwa nilai-nilai nasionalisme merupakan rasa keterikatan sekelompok orang (alash'abiyab) yang memiliki kesamaan tujuan untuk membangun suatu sistem tatanan kehidupan. Nilai-nilai nasionalisme ini dibangun atas pluralitas, persaudaraan, solidaritas dalam keberagaman, kesederajatan dan cinta tanah air. ${ }^{72}$ Menurut Ibnu Khaldun yang dikutip oleh Moesa bahwa nilainilai nasionalisme terdiri dari cinta tanah air, kebersamaan yang disertai jiwa patriotism dan juga perlawanan melawan penjajah. ${ }^{73}$ Yatim mengatakan bahwa nilai nasionalisme sudah dianggap

\footnotetext{
${ }^{70}$ Dokumentasi Pesantren Ngalah, (diambil tanggal 31 Juli 2017)

${ }^{71}$ Sartono. KartodirjoPembangunan Bangsa. (Yogyakarta: Aditya Media. 1993), hlm. 16

${ }^{72}$ Ali Maschan Moesa. Nasionalisme Kiai. (Yogyakarta: LKis. 2007), hlm.307

${ }^{73}$ Ali Maschan Moesa,. Nasionalisme Kiai. (Yogyakarta: LKis. 2007), hlm.216
} 
muncul manakala suatu bangsa memiliki cita-cita yang sama untuk mendirikan suatu negara dan bangsa. ${ }^{74}$

kata sya'ab di dalam al-Quran disebut sekali dalam bentuk jamak, yaitu: syu'uban. Pada ayat ini al-Quran telah memperkenalkan konsep bangsa (Nasionalisme), ${ }^{75}$ dengan kata lain bahwa Islam telah mengakui adanya rasa kebangsaan (Nasionalisme). Nasionalisme ini diwujudkan dengan adanya sikap saling mengenal, mengakui, dan menghargai identitas bangsa masing-masing individu yang berbeda dalam bingkai Bhinneka Tunggal Ika. Nasionalis (mencintai bangsa dan tanah air) di dalam Islam tidak ada larangan, sebagaimana digambarkan di dalam al-Qur'an bentuk persatuan untuk mempertahankan suatu Negara, bangsa, dan tanah air dari ancaman Negara lain yang ingin menjajah dan menguasainya. Hal ini disebabkan bahwa nasionalis merupakan salah satu kekuatan di dalam menjaga persatuan dan kesatuan bangsa dengan cara cinta bangsa dan tanah air. Senada dengan itu, menurut Purwasito bahwa "semangat kebangsaan diterjemahkan sebagai nasionlisme yaitu cinta tanah air atau patriotism."76

\section{KESIMPULAN}

Best Practices Nilai Karakter Multikultural Pondok Pesantren Ngalah Pasuruan meliputi:

Nilai Karakter Religius; Religius adalah sikap dan prilaku yang patuh dalam melaksanakan ajaran agama yang dianutnya, toleran terhadap pelaksanaan agama lain, dan hidup rukun dengan pemeluk agama lain.

Nilai Karakter Kemanusiaan; Nilai karakter kemanusiaan di Pesantren Ngalah merupakan core nilai yang menumbuhkan dan mengembangkan nilai karakter multicultural yang lain meliputi; (a) karakter kepedulian dan kedermawanan santri; (b) Nilai karakter persaudaraan, (c) Karakter Kasih Sayang, (d) Egaliter/kesederajaran;

Karakter Inklusif-Pluralis; Nilai karakter Inklusif-pluralis (terbuka menerima perbedaan) yaitu karakter yang dapat menerima dan dapat bergaul dengan santri yang memiliki latar belakang yang beragam. Tamu yang datang ke pesantren Ngalah semuanya - tanpa terkecuali--diterima dan disambut dengan ramah, dan santun, baik tamu yang itu muslim, maupun dari Non muslim, baik itu pencuri maupun polisi, semuanya dijamu dengan ramah, santun dan baik.

Nilai Karakter Toleransi (Tasamuh); Nilai Karakter toleransi bertujuan agar terjalin kerukunan, kerharmonisan, dan kebersamaan antar pemeluk agama dalam bingkai Bhinneka Tunggal Ika, serta menguatkan integritas bangsa dari kecaman-kecaman eksternal. Nilai Toleransi santri, meliputi; (a) Toleransi dalam Pergaulan Antar Umat Beragama, (b) Mengucapkan Salam Kepada Non Muslim, (c) Non muslim Masuk ke Dalam Masjid.

Nilai Karakter Luwas dan Luwes; Nilai luwas dan luwes (moderat) pada dimensi social sebagaimana di dalam penerapan hukum fikih. Moderat disini bukan berarti tidak memiliki prinsip, namun bersifat dinamis, atau fleksibel yang disesuaikan dengan kondisi dan situasi tertentu dalam menerapkan hukum. Berdasarkan pada hasil pengamatan bahwa nilai luwas tercermin pada sikap santri di dalam berpandangan dan berwawasan keilmuan yang banyak dan mendalam, baik keilmuan duniawi (umum) ilmu ukhrowi (diniyab) serta ilmu sosial kemasyarakatan.

Sedangkan nilai luwes tercermin pada sikap dan tindakan santri di dalam menghadapi permasalahanpermasalahan sosial kemasyarakatan dimensi Ubudiyah, muamalah, budaya, dan sosial politik dengan

\footnotetext{
${ }^{74}$ Badri Yatim. Soekarno, Islam dan Nasionalisme. (Jakarta: Logos Wacana Ilmu. 1999), hlm. 59.

${ }^{75}$ Secara etimologis kata Nasionalisme, akar kata dari nation yang berarti bangsa dan isme adalah paham, kalau digabungkan arti dari Nasionalisme adalah paham cinta bangsa (tanah air) (KBBI).

${ }^{76}$ Yaya Suryana, A. Rusdiana. Pendidikan Multikultural Sebagai Upaya Penguatan Jati Diri Bangsa: Konsep, Prinsip, dan Implementasi. Bandung: CV. Pustaka Setia. 2015.hlm. 238
} 
sikap yang bijaksana, ramah, santun, tidak mudah menyalahkan bahkan mengkafirkan orang lain yang tidak sefaham atau tidak sama dengan pandangannya, dengan tetap memegang prinsip-prinsip yang mengacu pada akar nilai-nilai inklusif menurut Hasan menurut yaitu taaruf, tasamuh, tawazun, tawasuth dan taawun, ${ }^{77}$ serta mengedepankan nilai-nilai manusiawi.

Nilai Karakter Demokratis; Karakter demokratis yang merupakan ide atau atau pandangan hidup yang mengutamakan persamaan hak dan kewajiban serta perlakuan yang sama bagi semua warga Negara. Menurut Ubaidillah demokrasi adalah kekuasaan atau kedaulatan rakyat, kekuasaan tertinggi berada dalam keputusan rakyat, rakyat berkuasa, pemerintahan rakyat dan kekuasaan oleh rakyat ${ }^{78}$ Demokrasi merupakan sikap kebebasan dalam mengambil sebuah keputusan pribadi baik bertujuan individu ataupun khalayak umum yang disertai penuh tanggung jawab yang diwujudkan dengan adanya pengakuan atas hak asasi manusia bagi setiap individu.

Nilai Karakter Nasionalis; Aktivitas yang dilakukan santri Pesantren Ngalah yang bermuatan pada nilainilai pancasilais yaitu adanya karakter atau sikap mengikuti perayaan dan kegiatan yang diselenggarakan Pesantren Ngalah sebagai bentuk dalam mengenang jasa-jasa para pahlawan, serta menghargai dan menjaga hasil jerih payah para pahlawan kemerdekaan RI yang telah gugur di medan pertempuan di dalam memperjuangkan kemerdekaan bangsa Indonesia. Kegiatan yang dilakukan di Pesantren Ngalah ini terdiri dari dua jenis kegiatan yaitu dimensi ritual dan sosial.

\section{DAFTAR PUSTAKA}

A. Ubaidillah, dkk., Pendidikan Kewargaan Demokrasi, HAM, dan Masyarakat Madani, Jakarta: IAIN Jakarta Press, 2000

Abdul Lathif Ibn Ibrahiim Ibn Abdul Lathiif al-Husain. Tasamuh al Ghorb Maal Muslimiin fi Asr wa al-hadir. Riyadh: Dar Ibn al-Jauzi, 1999

Abdul Majid dan Dian Andayani, Pedidikan Karakter dalam Perspektif Islam,

Abdullah Aly, Pendidikan Islam Multikultural di Pondok Pesantren, Telaab terhadap Kurikulum Pondok Pesantren Modern Islam Assalam Surakart, Yogyakarta: Pustaka Pelajar, 2011

Ali Maschan Moesa,. Nasionalisme Kiai. Yogyakarta: LKis. 2007

Alwi Shihab, Islam Inklusif: Menuju Sikap Terbuka Dalam Beragama, Bandung :Mizan, 1997.

an-Nahidil, Nunu Ahmad. 2016 "Pesantren dan Dinamika Pesan Damai" dalam Edukasi, Jurnal Penelitian Agama dan Keagamaan, Vol.4 No.3 Jakarta: Puslitbang Pendidikan Agama dan Keagamaan, Badan Litbang dan Diklat Departemen Agama RI, 2016.

Badri Yatim, Soekarno Islam dan Nasionalisme Jakarta: PT. Logos Wacana Ilmu, 1999.

Departemen Pendidikan Nasional, Kamus Besar Bahasa Indonesia Jakarta: Balai Pustaka, 2002.

Departemen Pendidikan RI, Ensiklopedi Nasional Indonesia, Jakarta: PT. Cipta Adi Pustaka, 1990 Jilid 11

Farida Hanum dan Setya Raharja..Pengembangan Model Pembelajaran Pendidikan Multikultural Menggunakan Modul Sebagai Suplemen Pelajaran IPS di Sekolah Dasar.Jurnal Penelitian Ilmu Pendidikan, Volume04,tahun 2011 Nomor 2

J. Suyuti Pulungan. Prinsip-prinsip Pemerintahan di dalam Piagam Madinah ditinjau dari Pandangan al-Qur'an Jakarta: Raja Grafindo Persada, 1996, hlm. 152 lihat juga Abdullah al Habsyi, Hak-Hak Sipil dalam Islam: Tinjauan Kritis. Tekstual dan Kontekstual atas Tradsisi Ablul Bait Jakarta; al-Huda, 2004.

Jamal Ma'mur Asmani, Buku Panduan Internalisasi Pendidikan Karakter di Sekolah, Yogjakarta: Diva Press, 2012

Kemendiknas, Pendidikan Karakter bangsa, dalam perpustakaan.kemdiknas.go.id/download/Pendidikan\%20Karakter.pdf

77 Muhammad Tolchah Hasan. Pendidikan Multikultural: Sebagai Opsi Penanggulangan Terorisme. Malang: Lembaga Penerbitan UNISMA.2016. hlm. 63

78 A. Ubaidillah, dkk., Pendidikan Kewargaan Demokrasi, HAM, dan Masyarakat Madani, Jakarta: IAIN Jakarta Press, 2000), hlm. 162 
Mohamad Mustari, Nilai Karakter Refleksi untuk Pendidikan Karakter. Yogyakarta: LaskBang PRESSindo. 2015

Muhammad Tolchah Hasan. Pendidikan Multikultural: Sebagai Opsi Penanggulangan Terorisme. Malang: Lembaga Penerbitan UNISMA.2016.

Murniati Agustian dan Yustina Rostiawati. Pendidikan Multikultural Sekolah Menengah Atas. Jakarta: Univ. Atmajaya, 2008.

Ngainun Naim dan Achmad Sauqi, Pendidikan Multikultural Konsep dan Aplikasi, Jogjakarta: Ar-Ruzz Media, 2008

Nurcholis Majid dalam Ridwan, Pengembangan Nilai-Nilai Islami dalam Pembelajaran PAI di SMA El Hikam Press, 2003

Santri Mallimin Muallimat, Buku Pedoman Santri Darut Taqwa dalam Berbangsa dan Bernegara: Sebagai Rujukan Kehidupan Berbangsa dan Bernegara. Edisi Revisi. Pasuruan, YudhartaAdvertising,tt

Santri Ngalah, Koleksi Khutbah Ala Pesantren Ngalah Cerminan Nilai Kedamaian. Pasuruan, Ponpes Ngalah, 2011,

Sartono. KartodirjoPembangunan Bangsa. Yogyakarta: Aditya Media. 1993

Sugiyono, Metode Penelitian Kuantitatif, Kualitatif dan R \& D, Bandung: Alfabeta, 2010

Syamsul Ma'arif, Pendidikan Pluralisme di Indonesia, Jogjakarta: Logung Pustaka, 2005

Syamsul Maarif. Pesantren Inklusif: berbasis Kearifan Lokal. Cet. I Yogyakarta: Kaukaba, 2015,

Syihab, M. Quraish, Membumikan al-Qur" an Bandung: Mizan, 1998.

Syihab, M. Quraish, Tafsir al-Misbab; Kesan, Pesan, dan Keserasian al-Qur'an, vol.13 Cet. IV; Jakarta: Lentera Hati, 2006.

Syihab, M. Quraish. "Wawasan Al-Qur'an: Tafsir Tematike Atas Pelbagai Persoalan Umat." 1996.

Taufiq Muhammad, Aplikasi MS. Quran In Word Kemenag, Lajnah Pentashih Mushaf al-Quran Kemenag. V.2.2. 2013.

Undang-Undang Republik Indonesia Nomor 20 Tahun 2003 tentang Sisdiknas \& Peraturan Pemerintah RI Tahun 2013 tentang Standar Nasional Pendidikan serta Wajib Belajar Bandung: Citra Umbara, 2014.

Yaya Suryana, A. Rusdiana. Pendidikan Multikultural Sebagai Upaya Penguatan Jati Diri Bangsa: Konsep, Prinsip, dan Implementasi. Bandung: CV. Pustaka Setia. 2015.

Yusuf, Achmad. "Strategi Pembentukan Karakter Inklusif-Pluralis Melalui Keteladanan Multikultural Kiai Di Pesantren Ngalah Pasuruan." Pendidikan Multikultural 3.1 2019,: 1-20. 